\title{
The Written Word: Literacy Across Languages ${ }^{1}$
}

\author{
Sara Harris and Jane Gilbert
}

To modern readers, the primary fact about a medieval manuscript page is often the language in which it is written (Latin, English, French, Welsh, and so on). However, medieval written words were situated not only within but also often across languages. Medieval British literacy was essentially comparative, evolving as it did against a background of at least two languages: most commonly, the formal Latin of the liturgy and the schools, and a vernacular mother-tongue. There were almost certainly no literate monoglots during the period covered by this volume. Interlingual relations were more evident, or more exploited, in some contexts than in others, as we shall show, but they were always at least latent. This chapter therefore favours a relatively flat and broad approach to 'medieval multilingualism'. On the one hand, we treat language choice as one among a range of elements that convey cultural context and meaningfulness, and which include the choice of text copied as well as codicological features such as format, script size and style, mise-en-page and mise-en-texte, practices of abbreviation or of commentary, and decoration. ${ }^{2}$ On the other hand, we foreground how linguistic variations run within and across distinct languages, communicated through style and register, local or supra-local usage, and orthography, as well as through code-switching, borrowing, quotation, and hybridisation. Drawing on the resources of more than one language was a pleasure and an art of medieval literacy, we argue, in many more cases than is commonly recognised.

The variety of languages written and spoken in medieval Britain offered scribes subtle opportunities to shape new readings of their texts. Throughout the medieval period, they would have learned to read and write first in Latin: the language of the Church, of diplomacy, of most legal documents, and of international scholarship. The vast majority of surviving manuscripts are written wholly in Latin. But to write in medieval Britain was to write within a multilingual nexus: although English was the most widely spoken vernacular, significant communities speaking French, Welsh, Cornish, Gaelic, Danish, and Norse were supplemented at different times by smaller numbers speaking Flemish, Hebrew, Italian, Breton, and other languages.

\footnotetext{
${ }^{1}$ We thank Anne Cobby, Simon Gaunt, Nicola Morato, Máire ni Mhaonaigh, Thomas O’Donnell, Judith OlszowySchlanger, Israel Sandman, Dirk Schoenaers, and, especially, Teresa Webber. Any mistakes remain, of course, our own.

${ }^{2}$ Other chapters of this volume treat some of these features in more depth, enriching the issues of language discussed here.
} 
Language knowledge was influenced by a person's region of origin or habitation. Social factors were also important, particularly where knowledge of elite languages was concerned. French offered access to the higher social echelons in England and to trade, land-holding, diplomacy, law, and travel on the continent and beyond, into the eastern Mediterranean and Adriatic. Latin was essential for access to Christian circles whose self-definition relied on learning, literacy, or ritual, its role paralleled by Hebrew for the significant number of Jews living in England between the Conquest and their expulsion in 1290. As this last point highlights, knowledge and practice of different languages in Britain varied significantly over the medieval period, affected by historical events and by micro- or macro-cultural shifts. The influence of events like the Viking invasions or the Norman Conquest appear (perhaps deceptively) easy to track, but complicated cultural strands and religious and ethnic politics might affect even a single milieu in a particular place over a few short generations. The varying status of French in England, for instance, defies generalisation. Moreover, survival rates have been uneven: catastrophic for Scotland and relatively bad for Wales, hence our focus here on England.

Medieval England's multilingual breadth ensures that its manuscripts are situated amidst and across different linguistic traditions. Medieval written language emerges as a nuanced series of negotiations between convention and innovation, where each element of the page carries its own cultural weight. To differing extents, the process of copying a text, whatever its language or languages, was shaped both by deliberate scribal decisions and also by less consciously considered responses to existing cultural pressures: how far to adhere to existing paradigms of written language and how far to experiment with reflecting the rhythms of everyday speech; whether to use an international language variety or a very local one; whether to employ the script and mise-en-page of the exemplar, to follow the existing conventions for the written form and type of text and its language, or to draw upon another tradition. Further questions were created by varying degrees of linguistic expertise and perception across audiences, times, and places: how far to include translations or glosses to aid or display (or sometimes to problematise) comprehension; how far to modernise, and how far to accentuate antiquity. Medieval English authors and scribes often evoked more than one set of conventions, relating their work to different genres and audiences and thus raising the question of the boundaries between them. Such overlapping associations imparted to words in many manuscripts a certain liminality-the 
sense of opening onto other languages and therefore contexts-which we aim to explore here through a number of case studies.

The potential for multiple linguistic interpretations on the part of scribe or reader is exemplified by a few lines jotted on the endleaf of Oxford, Bodleian Library, Bodley 340 . Endleaves are unusually receptive to scribal practices which depart from formal norms, and in this respect are atypical; however, the idiosyncratic jottings they preserve throw light on how language and languages worked for the communities producing or receiving the manuscript. Bodley 340 was part of a two-volume set designed to provide a comprehensive collection of the highly popular and widely disseminated Old English sermons by Ælfric, homilist, grammarian, and abbot of Eynsham (c.950-c.1010). Writing in the first quarter of the eleventh century, one main hand copied the full sermon series. Contemporary additions by this scribe and others indicate that he probably worked at Rochester Cathedral Priory, where the volumes apparently remained after the Norman Conquest. Annotations and glosses suggest that they continued to be read throughout the twelfth century; although Old English posed greater difficulties after this period, some readers into the sixteenth century still tackled the text. ${ }^{3}$ But Bodley 340 is most famous for a brief pen-trial made $c .1075-c .1100$ on its closing flyleaf (fol. $169 \mathrm{v}$ ). This seems to be part of a vernacular love song, but who was the singer?

Hebban olla uogala nestas hagunnan hinase hi<c e $>n d a$ thu - uu<at> unbidda $\langle t\rangle\langle u u>e$ nu?

All the birds have begun their nests, except for me and you. What are we waiting for now?

These lines have attracted wide attention as one of the earliest surviving traces of Old Dutch literature; but recent work has raised a more complicated set of linguistic possibilities. The poem's word forms are also compatible with the Old English local to Rochester, so we may have here not a Dutch, but a Kentish song. ${ }^{4}$ Whatever its original affinity, monks familiar with either side of the Channel could have shared its pleasures. Other details locate the text amidst an even

\footnotetext{
${ }^{3}$ On Old English after the Norman Conquest, see E. Treharne, Living Through Conquest: The Politics of Early English, 1020-1220 (Oxford, Oxford University Press, 2012).

${ }^{4}$ L. de Grauwe, 'Zijn olla vogala Vlaams, of zit de Nederlandse filologie met een koekoesei in (haar) nest(en)?', Tijdschrift voor Nederlandse taal- en letterkunde, 120 (2004), 44-56.
} 
wider audience. The scribe subsequently added a Latin passage above 'hebban olla vogala' (it is clear that the Latin came second because the scribe ran out of space for the final clause and had to insert it above the rest of the text). This closely translates the vernacular:

\section{Abent omnes uolucres nidos inceptos nisi ego et tu - quid expectamus $n u<n c>$ ?}

All the birds have begun their nests, except for me and you. What are we waiting for now?

Was this Latin addition intended as a scholarly gloss for those who did not understand a catchy local (or/and imported) song, or does it form the second verse of a multilingual lyric ${ }^{5}$ Writing in the decades after the Norman Conquest, the scribe would certainly have known of the Frenchspeaking monks recently arrived in Rochester from Benedictine houses in Normandy, and also of the Flemish churchmen whose migrations straddled the Conquest. Palaeographical evidence suggests that he may have been one of them himself: he wrote in a compact type of Caroline minuscule unmistakably derived from the Continent. ${ }^{6}$ Did he originally come from the Flemishor Dutch-speaking Low Countries, was he perhaps a Norman in England, or even a local man? And would his knowledge of Dutch or English have sufficed to read the Old English sermons in the volume, or did he pick the book up simply to try out his pen? Finally, we might ask how he would have understood the gender of the lyric's implied speaker, who could be construed as a man or a woman, an 'insider' or an 'outsider' to the monastery. 'Hebban olla vogala' invites us to read across and between Kent, Normandy, and the Low Countries; pre- and post-Conquest readers of Old English; scholarly glossing, popular poetry, and scribble; and English and Continental literary communities under the early Normans. At the juncture of these differing linguistic and interpretative traditions, the juxtaposition in this manuscript of a range of cultural resonances creates a new setting for a poem concerned with what it means to be 'at home'.

The example of Bodley 340 shows how we may miss important meanings if we approach medieval manuscripts with assumptions about language use that depend on nineteenth- and twentieth-century developments in nationalism and state formation. A substantial recent

\footnotetext{
${ }^{5}$ P. Dronke, 'Latin and Vernacular Love-Lyrics: Rochester and St Augustine's, Canterbury', Revue bénédictine, 115 (2005), 400-410.

${ }^{6}$ E. Kwakkel, 'Hebban olla vogala in historisch perspectief', Tijdschrift voor Nederlandse tall- en letterkunde, 121 (2005), 1-24 (p. 6).
} 
literature has interrogated how medieval notions of the relationships between language and social group compare with modern ones. ${ }^{7}$ Broadly speaking, some medieval pronouncements seem to invite nationalist treatment. Associations between language, law, and gens may be found throughout the period, and the issue of a 'national' vernacular arises especially in the fourteenth and fifteenth centuries. ${ }^{8}$ However, such notions differ from the modern versions underpinned by later ideas about states, ethnicity, and language (ideas that, though now sometimes considered outmoded, remain politically potent). Conversely, we should not assimilate medieval multilingualism to modern multiculturalism. The several languages of medieval manuscripts represent only a few, elite cultures (clerical, legal, mercantile, noble, etc.), most of which considered themselves to be transnational. ${ }^{9}$ In efforts to understand the varying, unfamiliar ways in which medieval language-scapes organised linguistic difference, not only historical scholarship but also modern linguistics, literacy studies, and translation studies have much to offer our sense of variances within particular languages and of continuities across them.

Historical linguists suggest that in many contexts, translating from Latin into the vernacular, or vice versa, may have appeared to medieval writers and readers primarily as a transfer between registers or discourses: usages stylistically appropriate to varying communicative situations and activities. Affectively and conceptually, transposition between a 'langue de culture' ('language of high culture') and a 'langue de diffusion' ('language of wide circulation') would be akin to what today is called intralingual translation (within the same natural language), rather than to modern interlingual translation. ${ }^{10}$ In a different mode, scholars working in several medieval areas have recently argued that what were once thought to be incompetent mixtures of different languages in many cases represent conscious deployments of specifically written language varieties which gained prestige from their variegated character. ${ }^{11}$ Such insights enrich our ability

\footnotetext{
${ }^{7}$ See, for example: Interfaces, 1 (2015), http://riviste.unimi.it/index.php/interfaces/issue/view/1/showToc; D. Wallace, ed., Europe: A Literary History, 1348-1418 (Oxford, Oxford University Press, 2016.

${ }^{8} \mathrm{~J}$. Wogan-Browne et al., eds., The Idea of the Vernacular: An Anthology of Middle English Literary Theory, 1280 1520, Exeter, University of Exeter Press, 1999.

${ }^{9}$ E. M. Tyler, 'Introduction: England and Multilingualism: Medieval and Modern', in E. M. Tyler, ed., Conceptualizing Multilingualism in Medieval England, c.800-c.1250, Turnhout, Brepols, 2011, pp. 1-13.

${ }^{10}$ C. Buridant, 'Translatio medievalis: Théorie et pratique de la traduction médiévale', Travaux de linguistique et de littérature, 21 (1983), 81-136 (p. 119). Linguists distinguish 'natural' languages such as Latin or Dutch from 'artificial' ones such as Esperanto or Klingon.

${ }^{11}$ J. Bisagni, 'Prolegomena to the Study of Code-Switching in Old Irish Glosses', Peritia, 24-25 (2014), 1-58; L. Wright, Sources of London English: Medieval Thames Vocabulary (Oxford, Clarendon Press, 1996).
} 
to grasp the fine medieval detail of some of the cultural negotiations that language choice always involves.

This chapter, therefore, focuses on the linguistically liminal and bridging practices of scribes and authors in medieval English manuscripts and on the multiple, complex literacies inscribed therein. In our next section, we look at some of the ways in which manuscripts create different effects by presenting 'book languages' alongside 'non-book languages'. We turn thereafter to discuss the centrality of translation to medieval reading and writing, stressing the connections between the transmission, acquisition, and display of knowledge on the one hand, and movement across and between languages on the other. Our final remarks return to question our starting-point, as we draw together these liminal, bridging practices to ask: what counts as a 'English' manuscript?

\section{'Book languages' and others}

Building on Charles Ferguson's classic essay on diglossia - a situation in which a community uses two languages but perceives and feels them to carry quite different valences, 'high' or 'low' — we suggest that in the Middle Ages, certain languages are presented as 'book languages', while others are not. ${ }^{12}$ Book languages define what literacy means in particular cultural contexts. They are deemed the proper vehicles of record, of administration and government, of literary heritage and cultural excellence, and of ritual and the sacred. They promise access to truths of various kinds: religious, scientific, historical, ethical, poetic, legal, and so on. They make things happen and shed lustre on what they express. Book languages are considered to possess stable grammatical structure and to be, if not universal and perpetual, at any rate resistant to changes of time and place. Their special functions and qualities supposedly make book languages markedly different from other linguistic codes in use, whether oral or written. Contrastingly, linguistic varieties perceived as 'non-book languages' display reduced prestige, agency, and efficacy; are less standardised, grammatical, and beautiful; are more responsive to space and time, and carry weaker truth-values. We shall argue below that medieval English manuscripts' use of non-book languages suggest the existence of creative ambiguity between the poles that Ferguson

\footnotetext{
${ }^{12}$ C. A. Ferguson, 'Diglossia', Word, 15 (1959), 325-40. Ferguson tests his model against multiple examples-including, fleetingly, Latin and (Romance) vernaculars (p. 337) - but it is intentionally an abstraction. Among useful deployments and developments of Ferguson's model are R. A. Lodge, French: From Dialect to Standard (London: Routledge, 1993); A. Putter, 'Code-Switching in Langland, Chaucer and the Gawain-Poet: Diglossia and Footing', in H. Schendl and L. Wright, eds., Code-Switching in Early English (Berlin: de Gruyter, 2011), pp. $281-302$.
} 
distinguishes. But firstly, we show how his characterisation of the 'high' illuminates medieval book languages.

Medieval perceptions of languages were often strongly hierarchical, and religious significance heavily shaped views of linguistic prestige. All the Abrahamic religions considered divine truth to be revealed not merely through the written word, but through particular forms of written language: Hebrew for the Torah, Arabic for the Quran. Although only a tiny minority of Christians in England could read Biblical texts in their original languages, many knew that the Old Testament was first written in Hebrew (which some thought to be the ancestor of all other languages, given by God to Adam in Eden) and the New Testament in Greek. If Hebrew, Greek, and Latin were for English Christians the tres linguae sacrae (the three sacred languages used in the inscription on Christ's cross), nevertheless Latin dominated. ${ }^{13}$ In practice most believers approached the Bible - the archetypal book - via St Jerome's fourth-century Latin translation, known later as the Vulgate or common version, which provided the basis for worship throughout Western Christianity. ${ }^{14}$

The authority inherent in Latin as the principal language of scripture was further, and variously, fortified, complicated, and sometimes destabilised by its historical inheritance and geographical context. Latin was the language both of the ancient Roman empire and its successor kingdoms and of the major Western religious institutions, many of which also looked to Rome; when used in other contexts, Latin carried some of the associated cultural, technological, and political prestige. For many Westerners, indeed, Latin was profoundly entangled in ideas of what books and writing meant per se. Litteratus meant Latin-literate, and Latin scribal conventions shaped presentations of other languages by providing ready-made models where writing was a fresh innovation, or by influencing existing conventions when people or texts moved into new cultural areas. Practices first developed in association with Latin endured in pages written from Ireland to Sweden, Poland, and Spain. Many western European vernaculars were encoded in Latin's writing system: a repertoire of letters that represented the phonology (system of meaningdistinctive sounds) of the Roman alphabet. ${ }^{15}$ As we shall see below, scribes sometimes struggled to fit this writing system to the particular phonology of the language in which they wrote,

\footnotetext{
${ }^{13}$ I.M. Resnick, 'Lingua Dei, lingua hominis: Sacred Language and Medieval Texts', Viator, 21 (1990), 51-74.

${ }^{14}$ New Catholic Encyclopedia, $2^{\text {nd }}$ edition, 15 vols. (Detroit: Thomson/Gale; Washington, D.C.: Catholic University of America, 2003): 'Latin (in the Church)', VIII, 360-66; 'Vulgate', XIV, 591-600.

${ }^{15}$ A different situation pertained in Eastern Europe, where the Orthodox evangelisers Cyril and Methodius adapted the Greek letter-system to create new alphabets for newly Christian communities.
} 
evidently reflecting on the challenge of vernacular orthography. True vernacular versions of the Roman alphabet took some time to emerge. Vernacular words were both dignified and overshadowed by inevitable comparisons with Latin and its cultural associations with the literature and learning of pagan antiquity and with Christian sacrality. Our case-studies below explore some of the ways in which their raising to book-language status generally meant emphasising resemblances with Latin manuscripts. For the distinction is not purely linguistic: the high and specific status of a book language is also created by association with particular writing systems, materials, formats, layouts, and paratext, as well as by the kind of text copied. Such features bestow as well as reflecting prestige, and are susceptible of wide imitation and adaptation. This enables considerable variety and fluidity in English manuscripts' presentation of book languages.

Moreover, not all the languages found in medieval English books claim the dignity proper to book languages. Many manuscripts include non-book languages in supporting roles; for instance, in interlinear glosses, as pen trials or owner's marks, or via quotation. If Latin (or an equivalent) primarily underpinned depictions of authoritative written language, scribes and authors also recognised that other factors could influence a text's credibility and utility. Nonscriptural languages could be endowed with intellectual prestige, not only when successfully evoking the paradigms of sacred texts, but also when demonstrating their links to specific royal, scholarly, social, professional, or regional circles. Temporal power did not only aspire to perpetuity, but was significantly anchored in the here and now. Linguistic authority in manuscripts was constructed through complex layers of references and, although many scribal choices and conventions recall the technologies and theologies associated with the writing of sacred or other institutionally sponsored languages, others are more deeply rooted in linguistic, grammatical, and visual details which advance the local, the oral, or the experimental. Although underrated today, this is a significant strand in the aesthetics and philosophies of medieval manuscripts: the effect of the vernacular line on Bodley 340's endleaf, for example, depends on it. At different moments and for different purposes, language in manuscripts can suggest either the eternal or the transient, while pages may play with distributing book and non-book status in order to draw out varied, often subtle effects.

The glossed Hebrew psalter, Paris, BnF, hébreu 113 (first half of the thirteenth century) illustrates both how complex and how culturally specific such effects may be. A small number of 
bilingual manuscripts apparently produced for Christian Hebraists interested in the Biblical language and text survive from medieval England. ${ }^{16}$ Most lay out the different texts in separate columns, a common pattern in contemporary Christian bilingual Latin-vernacular psalters (see the Eadwine Psalter, below). Our example is unusual in having been ruled only for the Hebrew text, and in having been copied from right to left (thus the page shown here is a verso side: fol. 2v). ${ }^{17}$ Such features highlight the manuscript's Jewish associations and credentials, to which we shall turn in a moment. The example also shows how medieval Hebrew manuscripts were influenced by the practices of dominant, non-Jewish cultures. ${ }^{18}$ The alternate red and blue colouring of the initial word of each psalm (here psalms 3 and 4) follows a fashion popularised by Parisian book production and widely found in Christian manuscripts, as well as throughout the large Ashkenazi Jewish areas of (at this period) England, northern France, the Rhineland, and northern Italy. Manuscripts in Hebrew script produced within this area during the twelfth and thirteenth centuries are so similar in appearance that modern scholars turn to other features to establish their date and place of origin. This similarity reflects the notable strength of Jewish networks and the mobility of Jewish individuals, but practitioners also made pronounced efforts to preserve traditional paradigms. This conservatism may have helped written Hebrew to approximate the ideal status of the book language in Christian as well as non-Christian eyes. And indeed in the manuscript hébreu 113, Hebrew is presented as the primary book language: the square Ashkenazi script is large, clear, formal, and beautiful, and occupies the page's central, ruled area. Latin is present but has seemingly lesser status, being marginal and interlinear. Nevertheless, the Latin writing in the margin, consisting of short quotations from St Jerome's Latin translation, the Hebraicum or Psalterium iuxta Hebraeos, refers the reader to a prestigious Latin book, whose presence at hand it implies. By virtue of being manifest on the page only in fragmentary, marginal form, Latin also claims the status of book language.

Still more culturally composite are the interlinear glosses, mainly in Latin but sporadically in insular French. ${ }^{19}$ In the middle of line 3 on fol. $2 \mathrm{v}$, for example, appears Latin

\footnotetext{
${ }^{16}$ J. Olszowy-Schlanger, Les Manuscrits hébreux dans l'Angleterre médiévale: Étude historique et paléographique (Paris: Peeters, 2003). For héb. 113, see especially pp. 19-22, 140, 181-87. Olszowy-Schlanger argues for an English origin on the basis of the mid-thirteenth-century English Latin hands, the insular French, and the runic alphabet on fol. 137v (pp. 19-20).

${ }^{17}$ http://gallica.bnf.fr/ark:/12148/btv1b60004143/f16.item.zoom.

${ }^{18}$ M. Beit-Arié, Hebrew Manuscripts of East and West: Towards a Comparative Codicology (London, British Library, 1992).

${ }^{19}$ Spellings like 'curuz' (1. 5) and 'purpris' (1. 9) on fol. $2 \mathrm{r}$ are strongly indicative of an insular origin for the scribe.
} 
surge[ren]t ('rise up'), whereas on the right-hand side (thus at the beginning of the line) we find the French mei anguissces (contrast the Latin hostes mei 'my enemies' next to it in the margin, whose function is not a gloss but a finding aid relative to Jerome's Latin text). The presence of these French words seems odd: surely a Christian reader sufficiently educated to tackle Hebrew had no need of a vernacular crib? But it is likely that the Christian copyist accessed the Hebrew initially via French: specifically, via translations of and commentaries (le azim) on Hebrew sacred writings, written in French, the everyday tongue of Ashkenazi Jews at this time (although they wrote French using Hebrew script instead of the Latin alphabet, with its Christian associations). The Latin interlinear glosses in hébreu 113 are either translated from or modelled on original vernacular glosses. That French should be the primary vehicle of sacred learning upsets the traditional Christian hierarchy of languages, which the language practice of this manuscript restores by relegating French to the occasional term. ${ }^{20}$ The end product may resemble the strictly hierarchical pages of the Eadwine Psalter, where the interlinear, insular French translation of the Hebraicum gives local colour and affect to the 'universal' text represented by the three complementary Latin translations of the psalms. However, BnF hébreu 113 is witness to some ways in which cultural contacts and practices that do not fit within monastic, or even Christian models, nevertheless took place in English monasteries and universities. ${ }^{21}$

Status as book language could fluctuate with larger cultural attitudes as well as across individual texts and manuscripts. In Northern and Western Europe, vernacular languages achieved 'book' status unevenly: at different times and rates, in different places, and in different contexts. An early eleventh-century manuscript written in Standard Old English would have carried a particular linguistic weight for contemporaries, since this regularised form of late West Saxon was also associated with the royal court. ${ }^{22}$ But after 1070, royal writs largely abandoned this form of English: the (now Norman) king's court and administration placed new weight on

\footnotetext{
${ }^{20}$ We have adopted for BnF hébreu 113 the argument advanced by Geneviève Hasenohr for the trilingual glossary from Ramsey Abbey; J. Olszowy-Schlanger et al., eds., Dictionnaire hébreu-latin-français de la Bible hébraïque de l'Abbaye de Ramsey (XIIIe s.), (Turnhout: Brepols, 2008), xxxvii-xli. For both manuscripts, the French could have been found in the exemplar or resulted from conversations with an interlocutor. Note that after fol. 7r, the interlinear glosses cease and the marginal finding aids become a fuller translation.

${ }^{21}$ Further evidence of language study is evident in vowel lists and glossaries on the opening endleaves, and on an endleaf which displays Hebrew, Greek, and runic alphabets, with their letter names, in Latin transcription, and the Lord's Prayer in Greek (written using first the Greek alphabet, then the Latin) (fol. 137v).

${ }^{22}$ For an introduction, see H. Gneuss, 'The Origin of Standard Old English and Æthelwold's School at Winchester', Anglo-Saxon England, 1 (1972): 63-83.
} 
French and Latin. ${ }^{23}$ A late eleventh- or early twelfth-century reader of a pre-Conquest English manuscript might or might not have preferred to make a copy which reflected the speech patterns of his or her own era more closely. Moreover, the boundaries between book and non-book language were profoundly permeable, both within the manuscript and outside it: at different times, readers could interpret the same language in different lights. This could spark unexpected developments. As Standard Old English gradually declined in cultural prestige, some scribes moved away from Anglo-Saxon norms: they were now reading their exemplars with an eye to experimentation. Crucially, their re-shapings of book language took place both in English and beyond it. Many of the earliest surviving manuscripts containing French texts were produced in post-Conquest England: ${ }^{24}$ it seems that the sophistication of Old English intensified interest in the potential of Old French to function as a book language. Thus, the conceptual parameters of individual languages often overlapped, informing, disrupting, and enriching written conventions.

These shifting views of book language emerge from habitually multilingual environments (which all literate environments were): scribes, authors, and audiences constructed and negotiated texts by drawing on multiple frames of linguistic expertise. Such frames could be pointedly juxtaposed or could co-exist harmoniously, sometimes within the same document. Oxford, Bodleian Library, Ashmole 328 was written in the mid-eleventh century by a single scribe. This manuscript is a copy of the Enchiridion, a text composed in 1010-12 by Byrhtferth, a monk at the Benedictine Abbey of Ramsey. It offers miscellaneous material loosely pertinent to the computus, the methods used to calculate various astronomical phenomena and moveable feasts (such as Easter). Byrhtferth envisages a wide-ranging audience across monks, priests, and minor clerics, from 'scholars and learned men' ('boceras and [...] getydde weras') to 'clerks and rustic priests' ('clericum and uplendiscum preostum'). ${ }^{25}$ Although fascinated by numerical esoterica, he was also eager to teach the basics of the calendar: computus calculations were an essential practical skill for the clergy. These twin considerations of the scholarly and the necessary may have influenced Byrhtferth's initial plan to compose the Enchiridion in Latin and the vernacular. He depicts English as a pedagogical support for the revelation of divine truth in

\footnotetext{
${ }^{23}$ The reasons for this change in royal policy remain unclear: D. Bates, ed., Regesta Regum Anglo-Normannorum: The Acta of William I (1066-1087) (Oxford, Clarendon, 1998), pp. 48-50.

${ }^{24}$ M. Careri, C. Ruby, and I. Short, Livres et écritures en français et en occitan au XII siècle: Catalogue illustré (Rome: Viella, 2011).

${ }^{25}$ Byrhtferth's Enchiridion, ed. P.S. Baker and M. Lapidge, EETS s.s. 15 (Oxford: Oxford University Press, 1995), pp. 120-1. Further page references given in parentheses refer to this edition.
} 
Latin, stating that it is included so that 'young men would therefore understand the Latin more easily' ('pæt iunge men mihton pe leohtlicor pæt Lyden ongitan', pp.120-1). But, in practice, Byrhtferth almost immediately lost interest in alternating Latin computus explanations with English translations. The task was 'to langsum' ('too tedious', p.20). Instead, he adopted a far more fluid structure: complicated and often recherché material is presented across both Latin and the vernacular. We might see these complementary idioms as forming a single, cohesive, and highly wrought writing style, which reflects Byrhtferth's enjoyment of arcane vocabulary in both languages. The linguistic contrasts and coherences facilitated by this structure are explored further in the different scripts of Ashmole 328. The scribe, following contemporary norms, visually marked out the text's two languages by employing a late style of Anglo-Caroline minuscule for the Latin, and Anglo-Saxon set minuscule for the Old English. However, a few details blur these distinctions: some Insular letter forms were used for copying not only English, but also Latin (a, horned $\mathbf{e}, \mathbf{f}, \mathbf{g}, \mathbf{r}$ ); and conversely, some Caroline minuscule letter forms for copying not only Latin, but English (h). ${ }^{26}$ Whilst Byrhtferth occasionally differentiates the functions of Latin and English, at other moments he implicitly depicts them as book languages of equal stature; indeed, he almost creates a composite, hybrid book language.

As literacy was a specialised skill, medieval texts were often performed to a group in a classroom, religious, or domestic setting; even where literacy was more widespread, performance continued to be a common means of consumption. Book languages were not limited to the page. In some cases, these contacts with the spoken word prompted profound re-imaginings of how written language might appear. In the twelfth century, the gradual shift away from the written norms of Standard Old English offered exciting opportunities to explore new ways of depicting the sounds of the vernacular. Oxford, Bodleian Library, Junius 1 preserves the only copy of the Orrmulum, a collection of English Gospel homilies written by one main hand. ${ }^{27}$ This scribe's lack of expertise caused him difficulties, resulting in a highly idiosyncratic manuscript. He used poor quality quills, ink, and parchment. His work seems so painstaking that it is presumed he can only be the text's author, who names himself as Orrm. An Augustinian canon, perhaps working at Bourne in Lincolnshire, he wrote and revised the manuscript until the early 1180 s. ${ }^{28}$ Using Old

\footnotetext{
${ }^{26}$ Byrhtferth's Enchiridion, ed. Baker and Lapidge, pp. cxv-cxvi.

${ }^{27}$ M. Parkes, 'On the Presumed Date and Possible Origins of the Ormulum', in Five Hundred Years of Words and Sounds: A Festschrift for Eric Dobson, ed. E.G. Stanley and D. Gray (Cambridge: D. S. Brewer, 1983) pp. 115-127.

${ }^{28}$ Parkes, 'Presumed Date', pp. 120, 122, 126-7.
} 
English and Latin sources, Orrm aimed to produce a text which would communicate the message of the Gospels to the laity as clearly as possible.

For Orrm, an important part of this clarity was phonological. He was unusually sensitive to the potential of written English to give guidance to the spoken voice, producing one of the most sophisticated depictions of Middle English sounds ever attempted. Orrm had a uniquely systematic concern with mise-en-texte (the presentation of writing on the page), particularly where it could aid pronunciation: he distinguishes the similar sounds normally included under a single English letter through diacritical accent marks (e.g. <a〉 vs <á>) and using different scribal forms (e.g. three varieties of $\langle\mathrm{g}\rangle$ ). He was particularly anxious that later scribes should imitate his gemination of consonants (e.g. $\langle\mathrm{t}\rangle \mathrm{vs}\langle\mathrm{tt}\rangle)$ :

7 whase wilenn shall piss boc

Efft operr sipe writenn,

Himm bidde ice patt het write rihht, [...]

7 tatt he loke wel patt he

An bocstaff write twizzess,

E33whær pær itt uppo piss boc

Iss writenn o patt wise.

And he who shall afterwards wish to copy this book another time, I ask him that he copy it correctly $[. .$.$] and that he take care that he write each letter twice,$ everywhere that it has been written that way in this book.

These scribal practices single out the manuscript as a distinctive aesthetic object. They give the pages of Junius 1 such an eye-catching appearance that Orrm's text superficially seems unprecedented, both in its written form, and in its interpretation of Middle English. But closer examination reveals the presence of England's other languages to varying degrees of visibility. Most evidently, a second, contemporary hand wrote Latin finding aids into the manuscript. More obliquely, the regularised orthographies of Latin and Standard Old English form an obvious point of comparison with Orrm's spelling system. Finally, some scholars have detected the potential influence of French in Orrm's attention to cultivating a convincing English accent: in 
multilingual Lincolnshire, his careful spellings may have been intended to ensure that francophone canons preached the homilies with correct pronunciation. ${ }^{29}$ In some ways, Orrm's English seems hyper-written in its strictly regulated yet idiosyncratic scribal conventions. But other motivations may underpin this insistence on textuality: the Orrmulum's orthographical fixedness may also respond to the profound fluidity of twelfth-century oral practices.

The notion of the book language, therefore, is not a simple one. Not all instances of a book language are equal: the perceived status of writing in any language depends on its time, place, and audience. Latin remained pre-eminent as a liturgical, academic, and administrative book language in medieval Britain, and much of its popularity rested on its international scope and unbroken classical legacy. When other linguistic codes aspired to book language status, they might mimic these qualities. But scribes and authors could also choose to ground their texts in geographically and temporally specific contexts, and the appearance of French, English, Welsh, Irish, and more, often indicates a wish to exploit the powers of what were used as book languages in particular contexts. In the same spirit, writers of Latin might elect to use either selfconscious archaisms or more modern lexis and syntax. The ambitious classicism of John of Salisbury is a long way from the Latin administrative documents whose idioms creatively reflect the vernacular paradigms of oral business practice. Far from being static or monolithic, practical instances of book languages were always subject to significant internal variation, prompted by the circumstances of composition of individual texts and manuscripts.

The scribes of other manuscripts also construct book languages by exploring the relationship between clarity and convention, transience and permanence, sometimes with priorities very different from those of Orrm. Vatican, Vatican Library, Ottobonianus Latinus 1474 considers a new problem: how to translate the mysterious, vernacular language of Merlin's prophecies for the consumption of an international, Latinate, scholarly audience. In the 1130s, the appearance of Geoffrey of Monmouth's History of the Kings of Britain had caused astonishment across Western Europe. Controversially, Geoffrey claimed to have found new material absent from standard sources like Bede: he depicted the ancient British kings as

\footnotetext{
${ }^{29}$ M. Worley, 'Using the Ormulum to Redefine Vernacularity', in The Vulgar Tongue: Medieval and Postmedieval Vernacularity, ed. F. Somerset and N. Watson (University Park, PA: Pennsylvania State University Press, 2003), pp. $19-42$.
} 
descendants of the Trojans, and greatly amplified the deeds of figures like Arthur. ${ }^{30}$

Contemporaries were quickly captivated by his work on the prophecies of Merlin: like the rest of the history, it purported to be a Latin translation from a very old manuscript written in ancient British. ${ }^{31}$ Merlin's obscure, allegorical language seemed to offer veiled references to contemporary events and future developments, temptingly inviting further elucidation. During the subsequent international craze for decoding the prophecies, one text stands out. While all other twelfth-century interpretations of Merlin's prophecies are based on Geoffrey's text, John of Cornwall wrote a new Latin translation and commentary which seem to be based on independent Brittonic sources. $^{32}$

Ottobonianus Latinus 1474 now offers our only witness to John's work. Folios 1-4 form a booklet written by a single scribe sometime between 1166 and 1225, subsequently bound together with a late-medieval cartulary. Writing in or just before 1154, John was attempting to reshape the local, oral, vernacular, and ephemeral into a book language shared by scholars across Latin Europe. The scribe has supported this academic presentation, carefully differentiating the scripts used for Merlin's verse and John's commentary. By wrapping this commentary around the main text to create an L-shaped layout, he creates a mise-en-page reminiscent of glossed Latin manuscripts for the academic study of the Bible and the Liberal Arts.

This Latinate setting for the vernacular conceals subtle linguistic elisions even as it displays the translator's mastery of his subject matter. John's text contains six Brittonic vernacular glosses: some are definitely Cornish, some definitely Welsh; others could be located across Wales, Brittany, or Cornwall. In contrast to the Latin translation, which is presented as a single, unified text, the glosses suggest work assembled from a variety of written, and perhaps oral sources. The scribe was not familiar with Brittonic languages, and has copied them without comprehension. He may not have been very careful because he did not anticipate that his readers would understand the vernacular glosses either. Rather than encouraging his audience to explore Merlin's language, the scribe may have included these vernacular fragments as a visual

\footnotetext{
${ }^{30}$ For the most common version of the text and a useful introduction, see Geoffrey of Monmouth, The History of the Kings of Britain, ed. M. Reeve, trans. N. Wright (Woodbridge: Boydell, 2007).

${ }^{31}$ See further J. Crick, 'Geoffrey of Monmouth, Prophecy and History', Journal of Medieval History, 18 (1992): 357-371.

${ }^{32}$ Edited and discussed in M. J. Curley, 'A New Edition of John of Cornwall's Prophetia Merlini', Speculum, 37 (1982): 217-49.
} 
authentication of John's credentials as translator. Instead of deepening understanding, the glosses heighten our sense of this prophetic text's complications and obscurity.

The individual cases discussed above represent only some of the varied effects which medieval scribes and writers created by presenting written words in many combinations of formats, styles, and languages. These effects could be employed to explore perpetuity and eternity, the sacred, the official, the universal, or the learned; but equally, they could emphasise the fragility, confinement, and immediacy of earthly life. These cases show, moreover, how the writing of Latin and vernacular tongues often advanced together-unsurprisingly, given the many crossovers between these languages which our case studies manifest. ${ }^{33}$ Written languages of all sorts were intimately connected to living voices.

\section{Knowledge and Translation}

Ottobonianus Latinus 1474 introduces our next section, which examines how medieval ideas and practices relating to 'knowledge' — its nature, presentation, and dissemination —involved, or even implied, the use of different languages. For medieval people, knowledge was typically found in translation. Important works were translated into Latin from other book languages or vernaculars to facilitate the transnational communication of learning, while translations from Latin into vernacular languages expanded the scope and flexibility of the target language, and in some cases also increased the number and social range of the educated. The typical presentation of an erudite manuscript — authoritative text supported by explanatory commentary — foregrounds translation, since the gloss which re-articulates and contextualises the primary textual material may be thought of as a free translation, intra- or interlingual. Indeed, the world history of translation sponsored by today's professional body for translators and interpreters, the Fédération Internationale des Traducteurs, regards the Middle Ages wistfully as a Golden Age when translators could 'omit passages and insert commentaries to an extent never again equalled in the history of translation in the West'. ${ }^{34}$ Whereas in modern publishing, translation is generally defined narrowly and commentary relegated to footnotes or appendices as mere accessories, medieval pages present both 'translation proper' (in the modern sense) and gloss as prestigious

\footnotetext{
${ }^{33}$ Linguistic historians commonly note the 'paradox' that expansion and development in written European vernaculars typically occurs in periods of renewed interest in classical language and culture; e.g. Lodge, French, pp. 129-30 (p. 129).

${ }^{34}$ J. Delisle and J. Wordsworth, eds., Translators through History, rev. edition (Amsterdam/Philadelphia: John Benjamins, 2012), p. 133.
} 
and significant components of translatio studii (the transfer of learning between cultures, often associated with that of political hegemony: translatio studii et imperii). ${ }^{35}$

Translation owed its high status largely to its foundational role in Biblical interpretation: later Christian translators could consider themselves the divinely inspired heirs of St Jerome. Medieval institutions with the necessary economic and cultural assets often responded to this prestigious exegetical legacy with thoughtfulness and flair. The Eadwine Psalter (Cambridge, Trinity College, R.17.1) was created in Christ Church Cathedral, Canterbury, c.1155-c.1160. ${ }^{36}$ This luxury volume offers a meditation on what translation can capture. Its superb penmanship, large dimensions and ostentatiously expensive parchment are matched only by its unusually comprehensive contents, which display the exceptional scholarly and artistic resources of the Christ Church scriptorium.

The Psalter situates itself in a complex network of insular, continental, and historical connections. A typical page features three columns for St Jerome's three different Latin translations of the Hebrew Psalms (known as the Gallicanum, Romanum, and Hebraicum). Each version appears alongside an accompanying study aid. The Gallicanum has been glossed with a Latin explanatory text (the Parva Glosatura of Anselm of Laon); the Romanum, with an English translation; and the Hebraicum, with a French translation. These respectively direct us to theological study at the University of Paris; to the long history of English translation at Christ Church; and to the fusion of these traditions with a new, socially prestigious vernacular following the Norman Conquest. This juxtaposition of French with the Hebraicum also draws attention to the compilers' Hebraist credentials (as in BnF hébreu 113). The presentation of Latin, French, and English as mutually reinforcing, complementary book languages is further supported by bibliocentric aspects in the visual programme. The manuscript's lavish paratextual materials include a famous portrait of Eadwine, after whom the volume is known by modern scholars, and who may be the main, skilful scribe. This stress on cutting-edge institutional expertise is combined with an awareness of wider continental legacies: the Psalter's finelypoised illustrations and mise-en-page recall the ninth-century Carolingian Utrecht Psalter, also at

\footnotetext{
${ }^{35}$ Technical translation terms are discussed in M. Shuttleworth and M. Cowie, Dictionary of Translation Studies, Manchester, St Jerome, 1997; London, Routledge, 2014. On medieval translation, apart from Buridant (n. xx, above), see particularly R. Copeland, Rhetoric, Hermeneutics, and Translation in the Middle Ages, Cambridge, Cambridge University Press, 1995.

${ }^{36}$ For an overview, see M. Gibson, T. A. Hislop, and R. W. Pfaff, eds., The Eadwine Psalter: Text, Image, and Monastic Culture in Twelfth-Century Canterbury (London: MHRA, 1992); Treharne reassesses subsequent scholarship on the English gloss (Living through Conquest, pp. 167-87).
} 
Christ Church. This not only signals the manuscript's authoritative nature, but flatteringly reminds those able to recognise the references to the Utrecht Psalter that they are members of an exclusive international network of cognoscenti.

In some ways, the Eadwine Psalter makes clear distinctions between languages: its script and mise-en-page distinguish between Latin, English, and French. Given that the manuscript was designed to encapsulate the best of Christ Church talent and traditions, this suggests the community saw its multilingualism as a valuable aspect of its inheritance. These careful linguistic distinctions also coalesce to form a larger page where the Latin, English, and French glosses, and the further languages they imply (Greek, Hebrew, Aramaic) are read in dialogue with one another.

Despite this emphasis on language and interpretation, both vernacular versions are awkward to use in their current form. The first English gloss was created through seemingly ad hoc recourse to a wide range of sources with varying levels of accuracy. The earliest French gloss was similarly problematic, featuring many lacunae. Both were later subjected to thoroughgoing programmes of correction to rectify difficulties with the initial choice of exemplar, but neither was fully revised. This may reflect hasty production for a high status patron, but it also elucidates the compilers' criteria for 'finished enough'. The fine detail of explication was apparently less important than the project's conceptual ambition: its trilingual mise-en-page carried more weight than its practical potential as a scholarly reference work. As the volume stands, it encourages us to explore translation as a large-scale form of hermeneutics. Knowledge here is generated and performed through simultaneous linguistic comparisons across Latin, French, and English, rather than being embodied in any single language.

The Eadwine Psalter's translations demonstrate the geographically and historically farreaching transfers of knowledge enabled by life in a multilingual monastic community in twelfth-century Canterbury. Our next two examples of the connections between knowledge and translation take us to the late medieval explosion in manuscript culture, and to lay contexts. A familiar modern narrative relates how a nationalistic attachment to written English emerges over the fourteenth and fifteenth centuries out of the twin contexts of the Hundred Years' War with France and of England's conflicts with Scotland, Wales, and Ireland. However, as will be seen, 
vernacular pride was characteristically more inclusive than exclusive of other languages and cultures. $^{37}$

Surviving in thirty-two copies or fragments, among them Cambridge, University Library, Dd. 3.53 (first half of the fifteenth century), Chaucer's Treatise on the Astrolabe (c.1391) was the writer's most commonly copied work after The Canterbury Tales. ${ }^{38}$ It purports to initiate the author's ten-year-old son into the mysteries of that exotic and 'noble [...] instrument' (fol. 1r), and exhorts the boy to master the object practically so as to open the way to further geographical and cosmological knowledge. ${ }^{39}$ The vogue for vernacular translations of learned works into French and English from the second half of the fourteenth century not only disseminated knowledge from specialist contexts to new audiences, but also expanded the resources, functions, and prestige of the target language by appropriating those of the source language — or rather languages, since English translations, for example, often drew upon earlier compositions in or translations into French, Latin, Greek, and Arabic (often with admixtures of Spanish or Hebrew). Chaucer opens his Treatise by requesting that the 'trewe conclusiouns' ('true conclusions') he imparts 'suffise' ('be appropriate and adequate') to his son in 'naked wordes in englissh' ('bare words in English') as well as they do to Greek clerks in Greek, to Arabians in Arabic, to Jews in Hebrew and 'to the latyn folk in latyn' ('to the Latin folk in Latin') - these last having first translated them into 'hir owne tunge' ('into their own language'), just as Chaucer himself has done (all quotations from fol. 1r). Chaucer's justification echoes Nicole Oresme's prologue to his French translation of Aristotle's Ethics and Politics for Charles V of France (1370). ${ }^{40}$ Copied in

\footnotetext{
${ }^{37}$ Although during the Hundred Years' War 'we can identify a rise in English nationalism, and the English aristocracy abandoned French in favour of English', over the same period 'the largest number of French loanwords entered the English language'; T. Nevalainen and I. Tieken-Boon van Ostade, 'Standardisation', in R. Hogg and D. Denison, eds., A History of the English Language (Cambridge: Cambridge University Press, 2006), pp. 271-311 (p. 274). Many of these loanwords were the antique-inspired terms that French itself was then elaborating. When investigating French lexis or French-derived lexis in English, it is useful to note that particular words or meanings are often recorded for Anglo-Norman earlier than for continental French; see the Anglo-Norman Dictionary, http://www.anglo-norman.net/.

${ }^{38}$ E. Talbot Donaldson, quoted in S. Eisner, ed., A Variorum Edition of the Works of Geoffrey Chaucer, vol. VI: The Prose Treatises: Part One: A Treatise on the Astrolabe (Norman, OK: University of Oklahoma Press, 2002), p. 28. ${ }^{39}$ A description of CUL Dd. 3.53 and a transcription of its Treatise are included in K. A. Rand Schmidt, The Authorship of 'The Equatorie of the Planetis' (Cambridge: D. S. Brewer, 1993), pp. 150-85. C. Burnett, The Introduction of Arabic Learning into England (London: British Library, 1997), is largely concerned with astrolabes and with astronomical and astrological learning.

${ }^{40}$ N. Oresme, Le Livre de Ethiques d'Aristote, ed. A. D. Menut (New York: Stechert, 1940), p. 101; Oresme ascribes to Cicero's Academica the idea that 'choses pesantes et de grant auctorite sont delectables et bien aggreables as genz ou langage de leur païs' ('things that are difficult and very authoritative are delectable and very agreeable to people in the language of their land'; Cicero is justifying summarizing Greek philosophy in Latin), and
} 
lavish presentation volumes and self-consciously grandiose, Oresme's learned texts introduced such beautiful and useful words as aristocratie, democratie, and architectonique, ornamenting with distinction and charisma both the French language and the king who presided over its ornamentation. Oresme's work forms part of a large cultural movement which in the late Middle Ages transformed French into a new 'ancient' tongue, at once innovative and antique, most obviously via the massive introduction of Latin- and Greek-derived lexis and the (re)Latinisation of existing word-forms and meanings. ${ }^{41}$ (Prose was the principal beneficiary of this enhanced status.)

Chaucer, in contrast, only glancingly refers his English compilation to the king as 'lord of this langage' (fol. 1v; 'lord of this language'). Instead he places it in a domestic, private sphere and emphasises its modesty and diminutiveness, addressing it to 'Litel Lowys my sone' (fol. 1r; 'Little Lewis, my son'). Unfamiliar technical lexis is carefully related where possible to the boy's 'latyn [...] smal' (fol. 1r; 'simple Latin'): 'than ben the daies and thes nyht illike of lenghthe in al the ${ }^{\wedge}$ world II [and] ther fore ben thise two signes called the equinoxiis' (fol. 6v; 'then the days and nights are of the same length throughout the world; and therefore these two signs are called the "equinoxes" [equal nights]'). The glosses for more outlandish, Arabicderived terms are supported by reference to a familiar, concrete, domestic world. Thus 'this forseide cenyth is ymagened to ben the v[er]rey point ov[er] the crowne of thyn heued' (fol. 7r: 'this aforementioned "zenith" is taken to be the point directly above the crown of your head'), while the azimuths are 'lik to the clawes of a loppe or elles like to the werk of a womanes calle' (ibid: 'like the legs of a spider or like the design of a woman's hairnet').

In their different ways, both Oresme and Chaucer occupy intermediate places on the notional spectrum stretching from what Lawrence Venuti calls 'domesticating' translation practice, 'an ethnocentric reduction of the foreign text to receiving cultural values, bringing the author back home', to the opposite pole of 'foreignizing practice, an ethnodeviant pressure on those values to register the linguistic and cultural differences of the foreign text, sending the reader abroad'. Both lay claim to the riches of the classical world and of the orient. The

further points out that in Rome, 'le langage commun et maternel, c'estoit latin' ('the vernacular and maternal tongue was Latin').

${ }^{41}$ On the antique turn in Middle French and the vocabulary explosion, see G. Zink, Le Moyen Français (XIV et XV siècles) (Paris: Presses Universitaires de France, 1990), especially pp. 82-121. Words in Middle French (thirteenth to sixteenth centuries) often have a different, usually more Latinate meaning than they did in the Old French of the twelfth and thirteenth centuries or than they have today; consult the Dictionnaire du Moyen Français (1330-1500), http://www.atilf.fr/dmf/. 
ideological situations they sketch are nevertheless quite different. Oresme, a noted Aristotelian scholar and philosopher of place, space, time, and motion, of cosmology and astronomy, of mathematics and economics, brings the resources of the university to dignify the royal court and ideas of kingship and of government. ${ }^{42}$ Chaucer's Treatise 'send[s] its reader abroad' into a world of exotic terminology and knowledge, but it does so under parental rather than royal guidance. ${ }^{43}$ His text appears comfortably removed from centres of public life and, despite its Oxford setting, it asserts no more than an amateur's engagement with advanced learning. Imputing the need for instruction to children, he tactfully portrays the adult layman as knowledge's purveyor as well as its consumer.

Chaucer's book is, nevertheless, an ambitious one. The diagrams that punctuate the text in this manuscript emphasise how the first section of the Treatise is organised by assembling an astrolabe in imagination, piece by piece. This stress on practical utility suggests that the technical language being elaborated in the vernacular is similarly instrumental, thus drawing our attention to its specialist vocabulary and methods of argumentation, and to the distinctive use of prose. ${ }^{44}$ The mystique underpinning Chaucer's declared effort to encourage boyish curiosity is represented by the Arabising names that the stars bear on the astrolabe's rete in the diagram shown in the manuscript (the first image of the astrolabe proper in CUL Dd. 3. 53, and well before the rete's description). 'Arabic' names lie alongside Latin ones but resist assimilation. The equivalence between 'Alhabor' and the dog-star (known today by its antique name, Sirius) is mutely conveyed by the dog's head, in a visual parallel to the text's glossing of Arabic terms by domestic objects. The vernacular acquires dignity by association with the highest branches of human knowledge; used correctly, an astrolabe can situate the user and everything else accurately in relation to the globe, the cosmos, and time. The exotic rete thus communicates the vast ambition of the translational project that seeks to build a bridge between contemporary everyday life and the highest, most inaccessible human knowledge. Chaucer, characteristically, miniaturises and domesticates his own contribution to this international project.

\footnotetext{
${ }^{42}$ S. Kirschner, 'Nicole Oresme', The Stanford Encyclopedia of Philosophy (Fall 2013 Edition), ed. by Edward N. Zalta, https://plato.stanford.edu/archives/fall2013/entries/nicole-oresme/.

${ }^{43}$ L. Venuti, The Translator's Invisibility: A History of Translation, $2^{\text {nd }}$ edition (London: Routledge, 2008 ), p. 15. Venuti's distinction is fundamental to recent discussions of translation's ethics and politics; for an introduction, see M. Inghilleri (and C. Baker), 'Ethics', in M. Baker and G. Saldanha, eds., Routledge Encyclopedia of Translation Studies, $2^{\text {nd }}$ edition (Abingdon: Routledge, 2009), pp. 100-04.

${ }^{44} \mathrm{~S}$. Lehmann, 'La Mise en scène du texte scientifique à la fin du moyen âge: propriétés macro- et microstructurelles', in O. Bertrand, ed., Sciences et savoirs sous Charles V (Paris: Champion, 2014), pp. 87-112. Only a minority of surviving Treatise manuscripts contain diagrams, and many were never intended to.
} 
Oxford, Bodleian Library, Bodley 264 offers us a different viewpoint on the English engagement with imported traditions and artefacts in the late medieval period, 'domesticating' an entire existing manuscript. The manuscript's first scribes created a comprehensive biography of Alexander the Great by incorporating into Alexandre de Paris's twelfth-century verse Roman $d^{\prime}$ Alexandre (fols. $3^{\mathrm{r}}-208^{\mathrm{r}}$ ) several independent French Alexander texts, such as the early fourteenth-century Les Voux du paon (fols. $110^{\mathrm{r}}-163^{\mathrm{v}}$ ) and Le Voyage au paradis terrestre, of $c$. 1260 (fols. $185^{\mathrm{r}}-188^{\mathrm{r}}$ ). Evidently made in the Low Countries in 1338-44, this beautiful manuscript travelled to England - it was, literally, 'translated'-since, on fol. 67r, an early fifteenth-century hand has added a note in English: ${ }^{45}$

Here fayleth a prossesse of pis rommauce of alixaud' pe wheche prossesse pat fayleth ze schulle fynde at pe ende of pis bok ywrete in engelyche ryme and whan ze han radde it to pe ende tornep hedur azen and turnep ouyr bys lef and bygynnep at pys reson Che fu el mois de may que li tans renouele and so rede forp pe rommauce to be ende whylis pe frenche lastep

Here an episode of this romance of Alexander is missing, which missing episode you shall find at the end of this book, written in English verse; and when you have read it to the end, turn back to this point, and turn over this page, and begin where it says: '[in French] It was in the month of May, when the spring returns', and so read on to the end of the romance, as long as the French lasts.

Turning obediently to the end of the fourteenth-century text (fol. 209r), we find that the fifteenthcentury annotator has added the story of Alexander's encounter with the king of the Brahmins, in Middle English alliterative verse. Variously entitled Alexander and Dindimus or Alexander Fragment $B$, the additional poem is often considered to be a fragment of a lost, longer English Alexander romance. Whether or not that is so, it is treated here as an interpolation into the frame text, of exactly the same sort as the other French poems. When he 'inserts' an independent

\footnotetext{
${ }^{45} \mathrm{M}$. Cruse discusses the manuscript in depth, although with little attention to its English phase (Illuminating the 'Roman d'Alexandre': Oxford, Bodleian Library, MS Bodley 264: The Manuscript as Monument (Cambridge: D. S. Brewer, 2011). For discussion of the additions to Bodley 264 carried out in England in the early fifteenth century, which also include two frontispieces and a French Marco Polo, see C. W. Dutschke, 'The Truth in the Book: The Marco Polo Texts in Royal 19.D.1 and Bodley 264', Scriptorium, 52 (1998): 278-99.
} 
Alexander text into the frame narrative at the appropriate chronological point in Alexander's biography, the fifteenth-century English scribe embraces the project of the book's first compilers to create 'a kind of verbal and visual summa Alexandriana', showing a high degree of cultural competence. ${ }^{46}$

The short passage on fol. 67r is not shy about interrupting the frame text or about marking its linguistic difference: it identifies that frame as 'frenche', and quotes verbatim the beginning of the next folio. It differentiates itself visually not only by hand and by ink (fading may have made this more obvious), but by the distinctive thorn (b) and yogh (3) characters, in common insular use for English but not for French. However, once again distinguishing features also work to bridge cultures and languages and to extend horizons. The early fifteenth-century insular reader here installed in the manuscript is evidently comfortable reading verse both in the linguistically demanding Middle English alliterative style and in French alexandrine laisses dating from the late twelfth to the mid fourteenth centuries. Thorn and yogh appear here in the late forms which underline their similarity to the $\mathbf{y}$ and $\mathbf{z}$ of Romance alphabets; moreover, the English hand also added French-language rubrics missing from other Alexandre texts in the manuscript. The English scribe builds into the manuscript both divergences and continuities, exhibiting insular practices as legitimate variations on the International Gothic style. ${ }^{47}$ The reworking of Bodley 264, therefore, introduced specifically insular elements into a valuable manuscript in such a way as to underline connections with the prestigious global and local traditions that it conveys. It is worth noting that these connections do not centre on Paris, often considered today to be the core of francophone cultural and political activity. The fifteenthcentury scribe uses insular French when supplying rubrics, and carefully copies the 'Che fu el mois de may que li tans renouele' that begins fol. $68 \mathrm{r}$ (fol. $67 \mathrm{v}$ presents one of several full-page miniatures). 'Che' identifies the language variety as Picard, the French used in the wealthy, politically and culturally distinct area that extended across the north of modern France and the

\footnotetext{
${ }^{46}$ Quotation from K. Busby, Codex and Context: Reading Old French Verse Narrative in Manuscript, 2 vols. (Amsterdam: Rodopi, 2002), vol. I, 308.

${ }^{47}$ On the English alliterative line as the equivalent of the French alexandrine, see, inter alia, R. Field, 'The AngloNorman Background to Alliterative Romance', in D. Lawton, ed., Middle English Alliterative Poetry and Its Literary Background: Seven Essays (Cambridge: Brewer, 1982), pp. 54-69 (pp. 60-63). On International Gothic, see P. Binski, 'Court Patronage and International Gothic', in M. Jones, ed., The New Cambridge Medieval History, VI: c.1300-c.1415 (Cambridge: Cambridge University Press, 2000), pp. 222-33.
} 
southern Low Countries. ${ }^{48}$ Shared in the late medieval period between the French kingdom, the Holy Roman Empire, and Valois Burgundy, this area nevertheless maintained close economic and political links with England, and was always a significant point of entry for English activity on the continent. Through the successful grafting of Alexander and Dindimus into Bodley 264, the wealth and expertise of the exotic East, as well as those of the Low Countries, accrue to an England which is also continental.

We have moved from Eadwine's parallel texts and multiple glosses, through the lexical enrichment of CUL Dd. 3. 53, to Bodley 264's repurposing of a prestigious imported manuscript. In each case, translation and multilingualism offer the opportunity to display impressive linguistic and cultural resources, wealth, and power. Their central and ambiguous position within any narrative of 'the rise of English' shows how the ambitions carried by domestic linguistic developments might be far from merely 'insular'.

Given the fundamental equivocations created by the bridging and liminal practices that we have outlined in this chapter, we may ask whether medieval readers knew what language a manuscript was employing at any particular moment, and, if so, how? In one sense, the answer is obvious: language choice was communicated not only through strictly linguistic means but through a variety of cues, ranging variously and in different periods from features of letter forms and lexis to page layout and genre. But in other ways, the multivalent resonances of all these elements ensured that anchoring the text within a single, specific language remained deeply ambiguous. Juxtaposing, translating, and evoking different languages in manuscripts encouraged cultural porousness, both as comparison and as contrast. We turn, therefore, to our final example of an 'English' manuscript, to ask: is it one?

\section{Conclusion: An 'English' manuscript?}

One of a group of around thirty courtly prose manuscripts made in late thirteenth-century Genoa by Pisan prisoners of war, Paris, BnF, français 1463 is witness to the northern Italian vogue for Arthurian materials. Rustichello da Pisa (or, as he calls himself, Rusticiaus de Pise) begins his Arthurian compilation by claiming that 'cestui Romainz fu treslaites dou liure monseingneu Odoard li Roi dengleterre a celui tenz qu'il passe houtre la mer en s[er]uise nostre Sire damedeu

\footnotetext{
${ }^{48}$ S. Lusignan argues that use of Picard increased while other French regional dialects were in decline: Essai d'histoire sociolinguistique: Le français picard au moyen âge (Paris: Garnier, 2012). Picard is commonly found in manuscripts in England, and several of its features are shared with or often found alongside insular French.
} 
pour c[on]quister le Saint Sepoucre' ('this romance was drawn from the book of my lord Edward, king of England, at that time when he crossed overseas in the service of our Lord God to conquer the Holy Sepulchre', i.e. 1270-74). ${ }^{49}$ There is a venerable medieval tradition of citing non-existent sources, and many modern scholars think that Rustichello was inventing his. Nevertheless, there is ample evidence that manuscripts belonging to owners from the various parts of Britain reached Italy and the eastern Mediterranean, just as others made the journey westwards. The cultural contact situations in which manuscripts were produced in Britain formed part of the networks of a much larger world.

BnF fr. 1463 does not only direct us towards British manuscripts lost today; it also raises more complicated questions about cultural identity. The letter forms, decoration, and illustrations are characteristically Italian, and the language is Franco-Italian (a literary koinè combining Italian with Old French features). Nevertheless, Edward's putative book (in what language?) underwrites that of Rustichello, which is privileged to relate 'plusor chouses [et] plusor battailles que furent entraus que ne trueueres escrit en trestous les autres livres pource que li maistre le trueve escrit eu livre dou Roi dengleterre' (fol. 1r, a37-b1: 'many things and many battles which befell between [the heroes] that you will not find written in all the other books, because the master found it written in the book of the king of England'). It is clearly important for the reception of this manuscript and its contents that its written words be felt to be 'English'. 'Englishness' connects it to the fountainhead that guarantees its authority. Emerging from the very land where its heroes, Tristan and Lancelot, adventured, and pointing towards the East where Grail romance and real-life crusade meet, it travels in the entourage of a king of the line of Uther Pendragon and Arthur. All three kings are represented by the royal figure who presides over fol. 1r of the manuscript, endorsing text and book. ${ }^{50}$ The transnational networks to which BnF fr. 1463 bears witness and the complexity of its construction of identity have parallels in many of the manuscripts that we have discussed above, and prompt our concluding question:

\footnotetext{
${ }^{49}$ Paris, BnF, fr. 1463, fol. 1r, a18-23. The manuscript has been digitized: http://gallica.bnf.fr/ark:/12148/btv1b60005205. For an edition and facsimile, see F. Cigni (ed. and Italian trans.), Il romanzo arturiano di Rustichello da Pisa (Pisa: Pacini, 1994). Cigni points out (pp. 23-24) that Rustichello could have met Edward elsewhere than at Pisa: for instance, in Sardinia, Sicily, Cyprus, Acre, or in French lands either in Italy or overseas. Rustichello later co-authored with his fellow Pisan prisoner Marco Polo the story of the latter's travels in Franco-Italian, Le Devisement du monde (Bodley 264 contains the French redaction).

${ }^{50}$ And perhaps alternatively or also Rustichello himself, who the text indicates is 'imagines desoure' (fol. 1r, a24: 'pictured above'); R. Trachsler, 'Le Visage et la voix: L'Auteur, le narrateur et l'enlumineur dans la littérature narrative médiévale', Bibliographical Bulletin of the International Arthurian Society, 57 (2005): 349-71 (pp. 37071).
} 
how then, in this complex cultural period, do we decide whether or not a manuscript is 'English', or even 'British'? 